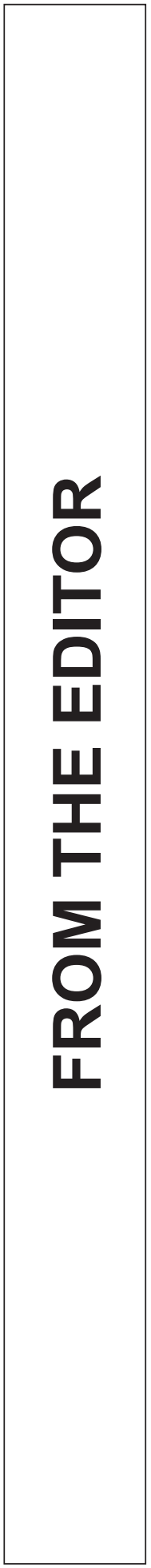



DOI : $10.14746 /$ ps.2019.1.1

\section{SECURITY - A NETWORK OF INTERCONNECTIONS. FROM THE EDITOR}

The human brain is comprised of over 100 billion neurons, which - combined with circa 2 trillion connections through synapses - constitute a complex and highly important network of connections. This network is additionally influenced by a variety of internal and external stimuli that determine our existence. To some extent, this resembles the security network, which is also comprised of many elements and factors affecting it. One of the most important, but frequently ignored, is the demographic factor. It may affect various aspects of security (e.g. internal or international) creating or escalating numerous challenges or threats regarding, for instance, wars and conflicts, mass migration and depopulation, growing financial disparities, poverty, water or food deficit, lacking or superfluous jobs, security related to the environment and raw materials and many other issues (Security, 2018).

The United Nations and the European Union, among others, highlight the importance of the demographic factor in their reports, emphasizing that the world's population will increase by over 1 billion by 2030, exceeding 8 billion. Demographic changes will, however, take a different course in various parts of the world. For example, the European population will decline (in 2015, it accounted for $6 \%$ of the world population, while its share will only be $4 \%$ in 2060), while the population of Africa will double (by 2040 or 2050) (White, 2017). The table below illustrates the scope and nature of demographic changes, presenting 30 countries which are forecasted to experience the largest population increases or drops by 2040 . The growth leaders will primarily include underdeveloped African countries, for example Niger (population increase by $115 \%$ in 2019-2040), Angola (86\%), Uganda (83\%), and the Democratic Republic of the Congo (81\%). The largest depopulation in the period concerned will occur in European countries, such as Bulgaria $(-15 \%)$, Latvia $(-15 \%)$, and Ukraine $(-12 \%)$ (Prajsnar, 2019).

Table 1

Countries forecasted to witness the largest population increases or decreases in 2019-2040

\begin{tabular}{||l|c|l|c||}
\hline \hline Country & $\begin{array}{c}\text { Forecasted } \\
\text { population changes } \\
\mathbf{2 0 1 9 - 2 0 4 0}\end{array}$ & \multicolumn{1}{c|}{ Country } & $\begin{array}{c}\text { Forecasted } \\
\text { population changes } \\
\text { 2019-2040 }\end{array}$ \\
\hline Niger & 2 & 3 & 4 \\
\hline Angola & $+114.7 \%$ & Portugal & $-7.4 \%$ \\
\hline Uganda & $+86.4 \%$ & Estonia & $-8.1 \%$ \\
\hline DRC & $+82.9 \%$ & Georgia & $-8.4 \%$ \\
\hline
\end{tabular}




\begin{tabular}{||l|c|l|c||}
\hline \multicolumn{1}{|c|}{1} & 2 & \multicolumn{1}{c||}{3} & 4 \\
\hline Somalia & $+80.0 \%$ & Japan & $-9.2 \%$ \\
\hline Tanzania & $+79.0 \%$ & Hungary & $-9.3 \%$ \\
\hline Mali & $+78.6 \%$ & Serbia & $-9.4 \%$ \\
\hline Zambia & $+78.2 \%$ & Romania & $-10.4 \%$ \\
\hline Burundi & $+76.0 \%$ & Lithuania & $-10.7 \%$ \\
\hline Mozambique & $+73.3 \%$ & Moldova & $-11.1 \%$ \\
\hline Chad & $+72.8 \%$ & Croatia & $-11.1 \%$ \\
\hline Equatorial Guinea & $+72.7 \%$ & Lebanon & $-11.1 \%$ \\
\hline Burkina Faso & $+72.0 \%$ & Ukraine & $-11.7 \%$ \\
\hline Malawi & $+71.6 \%$ & Latvia & $-15.1 \%$ \\
\hline Gambia & $+69.5 \%$ & Bulgaria & $-15.7 \%$ \\
\hline
\end{tabular}

Source: United Nations, see - A. Prajsnar, Demograficzna bomba tyka. Nasz region wyludnia się najszybciej na świecie, RynekPierwotny.pl, https://forsal.pl/artykuly (3.06.2019).

The relationship between demography and security has been examined in detail by some researchers, such as Gunnar Heinsohn, the German sociologist and demographer. He sees the above dependencies in terms of the War (violence) Index which he uses to compare the number of young (15-19 years) and older (55-59 years) men in a given area. The greater the disproportion between these two groups, the greater the likelihood of violence to be generated by young men who are dissatisfied with their own social position. According to Heinsohn, this process usually begins to escalate with an increase in crime, gang clashes or rebellions of young military officers. Its extreme form is war and armed conflicts. This is well illustrated by the example of Afghanistan, where the War Index was 4.7 at the onset of the intervention by the USSR (1979), meaning that there were 4,700 young people per 1,000 elderly men. At the beginning of the U.S. operation in Afghanistan (2001), the War Index amounted to 5.6, currently reaching a level of 5.9 (Heinsohn, 2009; Heinsohn, 2018).

In 2018, the countries (areas) with the highest War Index included: Uganda (8.08), Zambia (7.52), Lesotho (7.35), Malawi (7.04), Zimbabwe (6.81), Mali (6.61), Burkina Faso (6.46), Chad (6.40), Afghanistan (5.99), and Senegal (5.87). The lowest War Index was recorded in Hong Kong (0.59), Latvia (0.62), Slovenia (0.63), Macao (0.65), Germany (0.65), Belarus (0.66), Russia (0.67), Estonia (0.68), Bulgaria (0.68), and Spain (0.69) (Heinsohn, 2018: 7).

The correlations of demography and security are also addressed by Gary Fuller from the University of Hawaii, a former consultant to George H. W. Bush. In one of his analyses, he came up with the concept of the youth bulge, denoting a young generation significantly outnumbering the older, receding generation of men. The youth bulge is associated not only with rapid population growth, but also with high competition, for example, for jobs or social status, and often with the lack of prospects for establishing and sustaining a family at an adequate financial level. This promotes the attitudes that question the current institutional order and is conducive to aggressive actions, including participation in riots, criminal groups, wars, conflicts, terrorist attacks, etc. (Fuller, 1995). This is what we witnessed on a large scale, for example, during the Arab Spring (The Arab, 2016). 
The youth bulge is particularly noticeable in Muslim countries. Their population increased no less than twelve times in 1900-2018 (from 150 million to 1.8 billion). At present, approximately 24 percent of the world's population live in Muslim countries. Heinsohn emphasizes that over the same period the population of China more than tripled (from 400 million to 1.3 billion), and in India it quintupled (from 250 million to 1.2 billion). The population in selected Muslim countries is forecasted to increase from several to as much as over ten times in 1950-2050, as presented in detail in the table below.

Table 2

Estimated population change in selected Muslim countries in 1950-2050

\begin{tabular}{||l|c|c||}
\hline \multirow{2}{*}{ Country } & \multicolumn{2}{|c||}{$\begin{array}{c}\text { Population change 1950-2050 } \\
\text { (million) }\end{array}$} \\
\cline { 2 - 3 } & $\mathbf{1 9 5 0}$ & $\mathbf{2 0 5 0}$ \\
\hline Chad & 2 & 28 \\
\hline Afghanistan & 8 & 97 \\
\hline Iraq & 5 & 54 \\
\hline Jordan & 1 & 11 \\
\hline Pakistan & 39 & 350 \\
\hline Libya & 1 & 10 \\
\hline Yemen & 4 & 102 \\
\hline
\end{tabular}

Source: G. Heinsohn, Synowie i władza nad światem, Warszawa 2009.

Heinsohn estimates that persons in the 15-24 age bracket account for ca. 20 percent of the population of the Middle East and North Africa. Their number was about 95 million in 2005, and it will increase to 100 million in 2035. Although they are often qualified, have accommodation and food, the labor market is insufficient to guarantee them an adequate social position. This can generate various challenges and threats to internal and international security in Muslim countries, as well as their neighboring countries, and the destination countries (such as the European Union) for present or future massive influxes of migrants. The most important challenges and security threats include, among others, the following.

\section{Escalation of disintegration trends, including separatism, fundamentalism and terrorism.}

This is illustrated by an analysis which shows that at present there are around 200 modern states which accommodate approximately 3,500 large nations. Some of them desire to gain or regain their own statehood by various means (ranging from negotiations to military operations) as is the case, for example, of some Kurds, Basques, Palestinians, and so on. Another thing is a continued fairly high rate of support for Islamic terrorist or fundamentalist organizations (e.g. ISIS or Al-Qaida) among some Muslims. This is manifested, for example, by supporting terrorists in various ways, including by collecting or transferring funds, weapons, information, and so on. Importantly, more than 40,000 foreign volunteers fought in ISIS ranks in Iraq and Syria alone. 
Figure 1. ISIS foreign fighters by country and the number of returnees

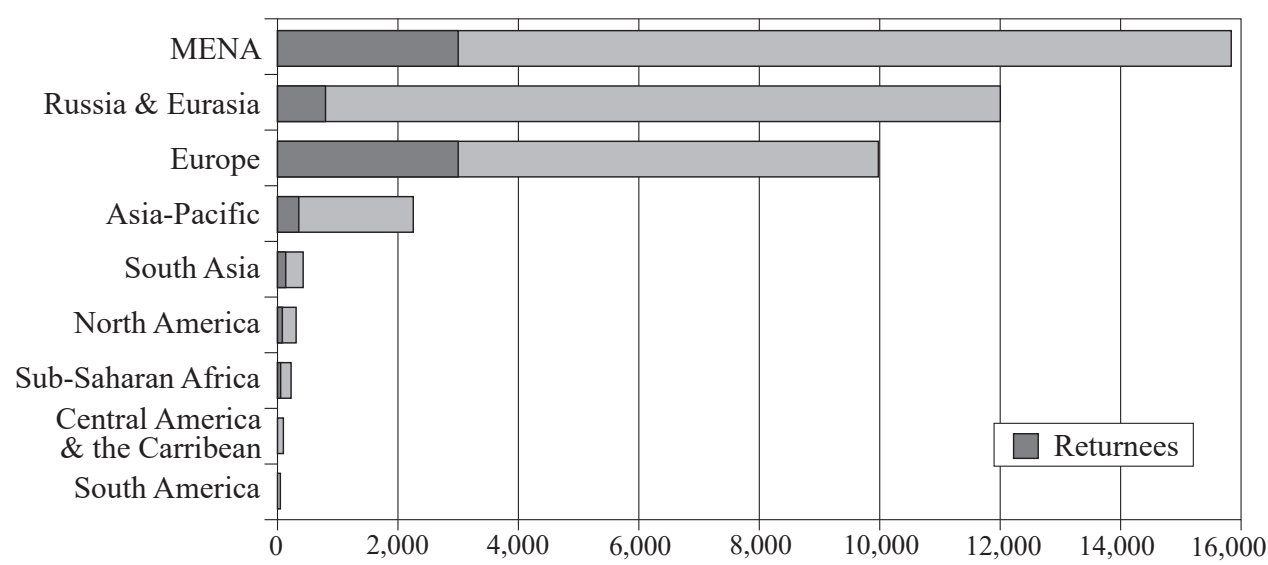

Source: Global Terrorism Index 2018, November 2018, START - NATIONAL CONSORTIUM FOR THE STUDY OF TERRORISM AND RESPONSES TO TERRORISM, visionofhumanity.org/app/uploads/2018/12/ Global-Terrorism-Index-2018.pdf (08.11.2019).

2. An increase in the number of disputes, conflicts and wars, both internal and international, caused by religious and ethnic (e.g. Islamic-Christian or Shia-Sunni conflicts), political (e.g. territorial disputes, competition for position and influence) and socio-economic (conflicts over resources, mass migrations, etc.) reasons. For example, in 2018, the vast majority of armed conflicts in the world took place in the countries witnessing the youth bulge phenomenon.

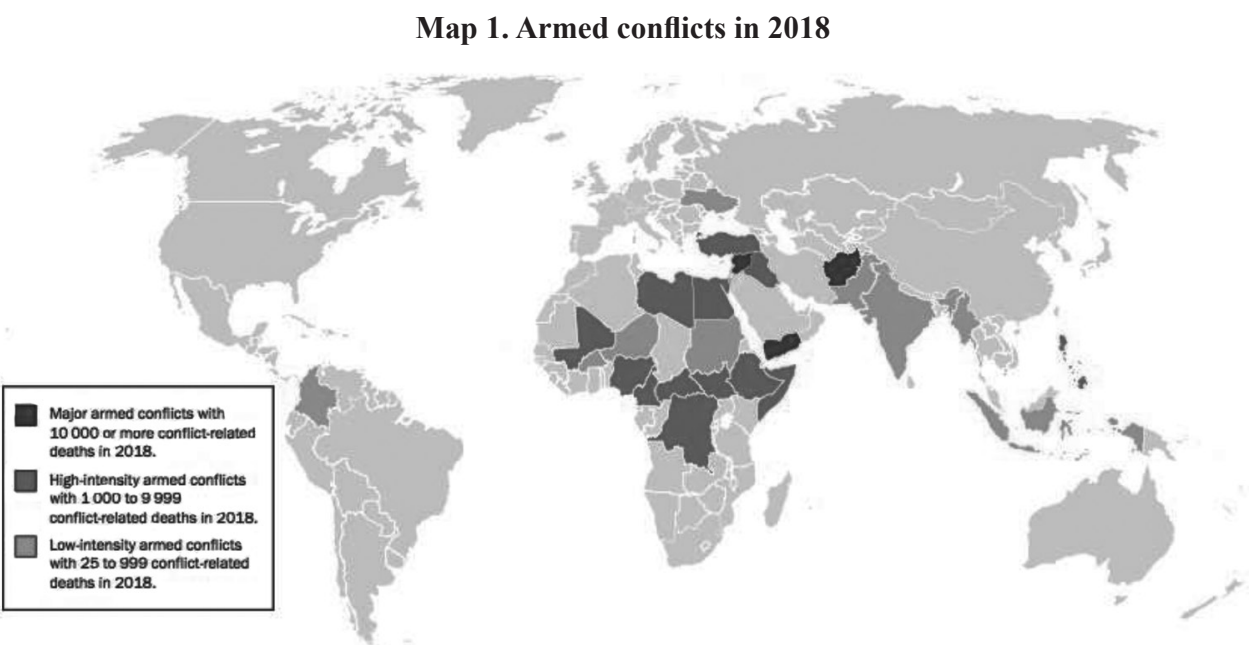

Source: SIPRI Yearbook 2019: Armaments, Disarmament and International Security, https://www.sipri.org/yearbook (06.11.2019).

In many cases, the list of countries in which wars are being waged overlaps with that of countries where the UN forecasts the highest demographic growth in 2019- 
2040 (see Table 1). This is true, for example, for countries such as Niger, Uganda, the Democratic Republic of the Congo, Somalia, Mali, Chad, Burkina Faso and others.

3. The high level of population growth in some Muslim countries and the resulting disproportionately large share of young men without prospects can lead to economic and social problems emerging or aggravating, such as poverty, unemployment, illiteracy or social exclusion. This will result in, among other things, intensified aggression, crime and various other forms of radicalization of social attitudes, which can be manifested through violent protests, riots or revolts of desperate people demanding the improvement of living conditions. This was the scenario, for example, of the Jasmine Revolution or the Arab Spring. The difficult economic and social situation of the countries forecasted to feature the highest population growth in 2019-2040 is shown in the table below.

Table 3

GDP per capita in \$ (at current prices, 2017) in the selected countries forecasted to feature the highest or lowest

population growth

\begin{tabular}{|l|c||}
\hline \multicolumn{1}{|c|}{ Country } & $\begin{array}{c}\text { GDP per capita } \\
\text { \$ }\end{array}$ \\
\hline Niger & 300 \\
\hline Angola & 4,100 \\
\hline Uganda & 600 \\
\hline Democratic Republic of the Congo & 400 \\
\hline Somalia & 400 \\
\hline Bulgaria & 8,200 \\
\hline Latvia & 15,500 \\
\hline Ukraine & 2,600 \\
\hline Lebanon & 8,800 \\
\hline Croatia & 13,300 \\
\hline
\end{tabular}

Source: World Bank Open Data, World Bank 2019, https://data.worldbank. $\operatorname{org}(28.10 .2019)$.

4. The escalation of demographic processes combined with the destabilization of the internal situation in some Muslim countries may lead to another intensification of mass migration flows. Heinsohn estimates that currently 150 million people want to emigrate from North Africa and the Middle East to Europe, a number that may increase to 270 million by 2050 . Even if only 10 percent of them pursue their desire, the countries of their destination will face very serious problems of a political, legal, economic and social nature related to, for example, the decision on admission and possible relocation of migrants, the response from local elites and public opinion, ensuring security, providing adequate financial resources, sealing or closing borders, etc.

More and more often, migrants are becoming a bargaining chip in the internal and international politics of individual countries. This was actually the case during the election campaign in many European Union member states, especially following the 2015 migration crisis when 1.2 million people came to Europe. Another example is the attitude of Turkey, which carried out an armed operation against Kurds in the border- 
land of Syria in 2019, threatening EU members who protested against this campaign with the opening of Turkish borders and thus sending several million migrants from its territory to the EU.

Another mass influx of migrants to the European Union could also increase the threat of terrorist attacks. On the one hand, this applies to activities carried out by Islamic terrorists in hiding or seeking support among migrants. On the other hand, it is necessary to take into account the cases of terrorist acts perpetrated by extremist groups (e.g. right-wing, left-wing or separatist groups) who, for various reasons, oppose or support the influx of migrants.

The majority of the texts in the latest issue of Przeglad Strategiczny [Strategic Re$v i e w]$ refer to the issues of network-like links between security and other issues. They are grouped into several thematic blocks. The first one, THE THEORY OF INTERNATIONAL RELATIONS AND SECURITY, includes five interesting texts, such as: Why is there no philosophy of International Relations, or Philosophy of Political Science?, Revisiting Mackinder's Heartland Theory: Identifying the Emergence of a Complex Power Competition in the Indian Ocean Region, Civilizational Structure of Regional Integration Organizations, Anxiety and Safety - the Ideology of the Consumer Society and A Global Approach to the Development of the Methodology of the Ukrainian Security Environment.

The second, highly important, section of the journal is dedicated to the issues of INTERNATIONAL SECURITY. It also features five texts, arranged in the following order: EU-NATO Partnership in 2017-2018 - Towards a New Model of Effective Response to Threat, Central Europe and NATO Transformation 2014-2018, Russian Politics Toward Ukraine: was there ever a strategic partnership, African Dimension of the Belt and Road Initiative and Dilemmas Related to the Poland's Participation in the Chinese Belt and Road Initiative.

Another approach to the topic of security is presented in the third section of the journal, entitled DOMESTIC ASPECTS OF SECURITY. Four texts were recommended for publishing here, discussing the following case studies: Migration Policy as an Instrument of Ensuring National State Security, Security Priorities and their Perception by Local Communities. A Survey of the Population in Wielkopolska 2015-2017, Social Determinants of Crime and Hatred Incidents at Mass Sports Events in Poland and The Issue of Self-Defence Based on Crisis Management and the Combat System Krav Maga.

Another thematic section in our journal concerns ECONOMIC AND SOCIAL SECURITY and features six texts: Mega FTA as a Signal Against Trade Protectionism Focused on the EU and Japan, China's Strategic Economic Growth (1978-2018), Dimensions of Social Diversity in Europe, Political Security in Authoritarian Systems with a Resource Rent Economy: a Result of the 'Social Contract' and High Resource Prices?, Water as a Weapon of War in the Tigris-Euphrates Basin and Selected Aspects of Iran's Hydrological Security.

The above topics are complemented by the section on MEDIA AND HUMAN ASPECTS OF SECURITY. It includes four texts which address the following issues: The effect of the 'China factor' on Taiwan's media system security as an example of the 'privatization and outsourcing' of censorship and propaganda in the digital age, 
Digital Intervention in National Political Systems in the Conditions of Contemporary Information Society, Non-Governmental Organizations as Actors of Ukrainian Politics of Memory and The 'museums of the frontline' in Stepanakert or on the Armenian remembrance of the armed conflict with Azerbaijan.

This issue of the Przeglad Strategiczny is pertinently concluded by the REVIEWS OF SCIENTIFIC EVENTS AND JOURNALS, featuring the reviews of selected academic journals and conference reports: SIPRI Yearbook 2018. Armaments, Disarmament and International Security, Russian Scientific Journals in the Area of IR - 2018 Review, The USA and Poland after 1989 and Perceptions of China's Role in the MENA Region. The 5th China and the Middle East and North Africa Conference.

I would like to thank the entire Editorial Board for preparing the twelfth issue of Przeglad Strategiczny and - on behalf of the Board and myself - I hope that reading this issue will encourage both discussion and academic reflection. Both these elements - discussion and reflection - are closely interrelated, and are imperative for the further advancement of academia, including strategic studies and security research.

\section{Sebastian WOJCIECHOWSKI Editor in Chief}

\section{REFERENCES}

Frieden J., Lake D., Schultz K. (2016), World Politics, New York-London.

Fuller G. (1995), The Demographic Backdrop to Ethnic Conflict, in: The Challenge of Ethnic Conflict to Notational and International Order in the 1990's, Washington.

Global Terrorism Index 2018, November 2018, START - NATIONAL CONSORTIUM FOR THE STUDY OF TERRORISM AND RESPONSES TO TERRORISM, visionofhumanity.org/ app/uploads/2018/12/Global-Terrorism-Index-2018.pdf (08.11.2019).

Heinsohn G. (2009), Synowie i władza nad światem, Warszawa.

Heinsohn G. (2018), Islamski index wojny, www.ptft.pl/images/srodek/2019/Gunnar\%20Heinsohn \%20Islamski\%20index\%20wojny/Gunnar\%20Heinsohn.pdf (07.11.2019).

Higgins-Bloom K. (2018), Food Fight, in: The Future of War, "Foreign Policy".

Kryzys a pozycja międzynarodowa Zachodu (2011), ed. R. Kuźniar, Warszawa.

Population and Vital Statistics Report (2019), Statistical Papers Series A Vol. LXXI, Data available as of January 2019, New York 2019, https://unstats.un.org/unsd/demographic-social/products/vitstats/sets/Series_A_2019.pdf (10.11.2019).

Prajsnar A. (2019), Demograficzna bomba tyka. Nasz region wyludnia się najszybciej na świecie, RynekPierwotny.pl, https://forsal.pl.

Security Studies (2018), ed. P. Williams, M. McDonald, London-New York.

SIPRI Yearbook (2019): Armaments, Disarmament and International Security, https://www.sipri.org/ yearbook (06.11.2019). 
The Arab Spring (2016), ed. M. Haas, D. Lesch, Routledge.

Wheeler T. (2018), In Cyberwar, There are no Rules, in: The Future of War, "Foreign Policy".

White Paper on the Future of Europe (2017), Reflections and scenarios for the EU27 by 2025, Brussels.

Wojciechowski S. (2010), The Problems of Europe in 21st Century, in: The Faces and Problems of Modern Europe. Case Studies, ed. J. Jeszka, S. Wojciechowski, Poznań.

World Bank Open Data, World Bank 2019, https://data.worldbank.org (28.10.2019). 